\title{
About Sert's drawing for Harvard planning, a reference for pedagogical innovation?
}

\author{
Jesus Esquinas-Dessy ${ }^{10000-1111-2222-3333]}$, Isabel Zaragoza ${ }^{2[111-2222-3333-4444]}$ and Paula \\ Esquinas $^{3}$ \\ ${ }^{1}$ Universitat Politècnica de Catalunya, Barcelona 08014, Spain \\ ${ }^{2}$ Universitat Politècnica de Catalunya, Barcelona 08014, Spain \\ ${ }^{3}$ Area Metropolitana de Barcelona, Barcelona, Spain \\ jesus.esquinas@upc.edu
}

\begin{abstract}
The aim of this communication is to show some reflections on the graphic re-presentation used by Sert to "make understand" the suitability of the urban planning proposal that he presented to Harvard University to guide its growth in the middle of the 20th century, in order to evaluate how that graphic language is the result of a rational and universal culture especially disciplined, as well as how the given context transformed a generic visual rationality into a more specifically rooted in the urban conditions of the site, in the human activity of its users and, in all the objectives of the assignment.

Recently, Sert's work is contemplated as blurred among the dense architectural culture of the Modern Movement, and his experience in urban planning is not perceived as a continuous evolution of his functionalist vision of the city. However, there are aspects in his multifaceted experience as an architect that make understand his work under a humanist and existentialist point of view with a singular graphic language.

Our work brings to light the narrative nature of the set of graphic material presented throughout the Harvard University Planning document, focused mainly on the impactful capacity of the graphic resources used. The research achieves an original and reasoned interpretation of some graphic strategies used by Sert to persuade a diverse audience with his thoughts, and where artistic references are fundamental
\end{abstract}

Keywords: Architectural representation, Sert, Modern movement, Urban planning, Teaching innovation. 


\section{$1 \quad$ Introduction}

The current disruptive change of technologies is identifiable as a new age of divided representation [1], similar to that at the beginning of the Renaissance when the statement of perspective laws meant a stimulating cultural change. Simultaneously, the new graphic resource caused an innovative look to the historical legacy of ancient Greece and Rome.

Related to this interest in looking carefully historical legacies, the work of Josep Lluis Sert, as a committed "activist" of the modern movement and conceived with rigorous ideological reflections, is a useful theoretical contribution as a timeless reference for the architectural practice.

Recently, the figure of Sert is seen as "blurred and misunderstood in contemporary architectural culture" [3] and his experience in urban planning, more linked to theoretical diffusion than to professional practice, is interpreted characterized by a continuous evolution of his initial functionalist vision of the city, to another more humanist and existentialist. However, its significance as an urban planner is completely justified, by its ideological activity in the influential CIAM (Fig.1), by its academic responsibility at Harvard, or by its ties with the art world. Therefore, it is enough to intuit that his work contains a valuable graphic language.
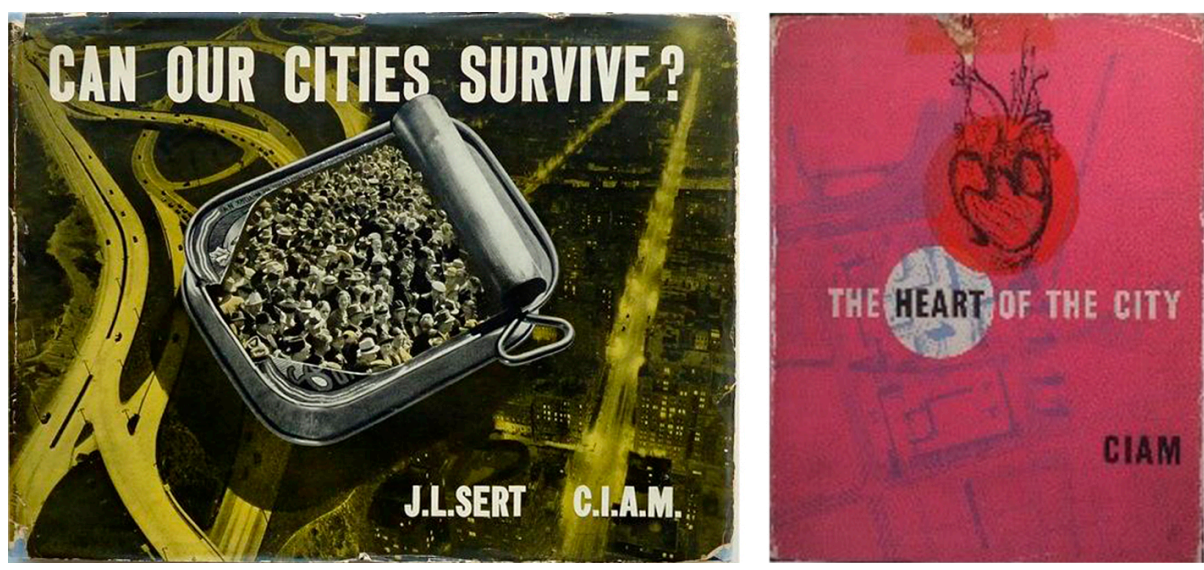

Fig. 1. Cover of the renowned illustrator Herbert Bayer, trained at the Bauhaus and collaborator of Sert, in CIAM publications. Left: Can our Cities Survive? 1942, written by Sert. Right: CIAM 8, The Heart of the City, 1952, co-edited by Rogers, Sert, Tyrwhitt.

Harvard Planning is considered urbanistically as a paradigmatic implementation of university in the city [3]. It is a work of maturity, when it already surpassed an abstract interpretation of an orthodox functionalism of the city, he had evolved into a new humanism and existentialism and, where intentional artistic references were glimpsed in his representation [4].

The examination of the original material of Sert's work for this planning [5] reveals a rational "story" intended to "persuade", in which the graphic representation has a 
key role and, whose successful result supports it as a useful model of graphic narrative, and therefore, necessary in the pedagogy of architectural representation.

This look is possible thanks to specialized archives, such as the Special Collections of the French Loeb Library of the Harvard GSD, which carefully guard these original graphic documents and which, as with unbuilt architectures, pedagogically allow reinterpretation of the thoughts that configured them [6].

New technologies allow us to observe and, therefore, draw and teach reality in a different way [7], and that possibility, adequately encouraged by past timeless experiences, as in the stimulating Renaissance, is an open door to innovative creativity every once more insistently demanded.

\section{A humanistic planning for Harvard}

Sert arrived to the United States in 1941, at his 40, and together with Wiener founded the office Town Planning Associates, TPA, dedicated to architecture and urban planning, which was especially focused on Latin America. This experience that lasted until 1958, accompanied by a continuous and progressive self-criticism, bequeathed a whole series of "functional" city plans, which illustrated the International Congresses with concrete examples of that "modern" urbanism.

Sert's planning for Latin American cities show the controversies and new formal directions that modern urbanism took as its social significance changed throughout the decade [8]. Although they were almost never implemented, they allowed Sert to develop a graphic language of great synthetic capacity and unavoidably attractive [8] (Fig.2). The shadow of the teacher Le Corbusier and his artist friends Miró, Leger or Picasso is not far...
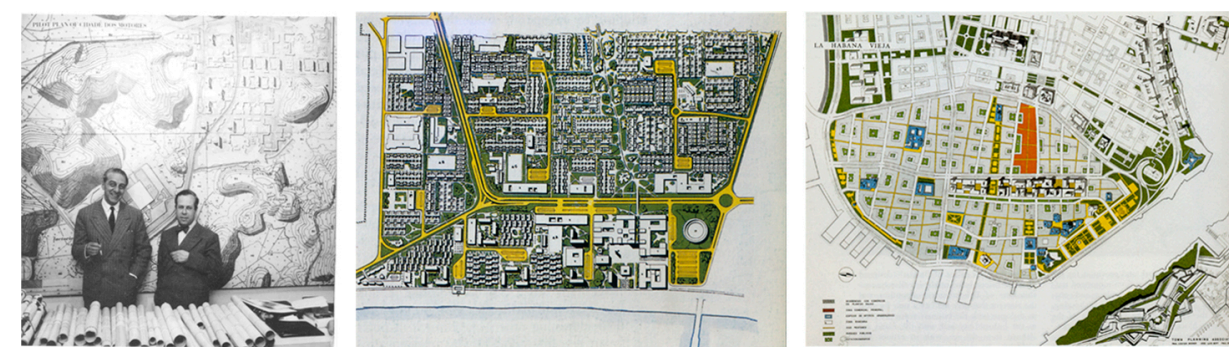

Fig. 2. Sert's urban planning for Latin America. Left: Wiener and Sert presenting the Cidade dos motores. Source: [8]p.168. Center: Chimbote. Source: [4]p.131. Right: La Habana. Source: [4] p.184.

Thus, endorsed as an experienced and self-critical urbanist [9], when he was about to finish the 30-year historical cycle of CIAM, in 1953, he was named dean of the Harvard Graduate School of Design and, at the same time, architecture studies director of that school replacing Gropius. In this academic context, Sert has the opportunity to apply his "functionalism" to Cambridge's historical complex in the United States. It is 
1957 when the president of Harvard University orders him the advising of a planning office for the entire Campus. The same year, he chairs the Cambridge City Planning Commission where he establishes a program to stop the growth of the university at the expense of the city [10].

The urban proposal [re]presented in a document, which has been disseminated iconically through only "one of two" images (Fig.3), which synthesize urban ideas of a document where there is more.

The first image is published, just ending his responsibility at Harvard, in a book that as a catalog collects the work done by Sert until then [11] (Fig.3left). Harvard Planning is represented as an exciting "green" environment, typical of rationalist urbanism.

Twelve years later, a paperback book on Sert's work [12] shows a second image. (Fig.3right). It is a single plan; the university plan is similar, although here, it incorporates the drawing of the roofs of the planned buildings, already constructed.
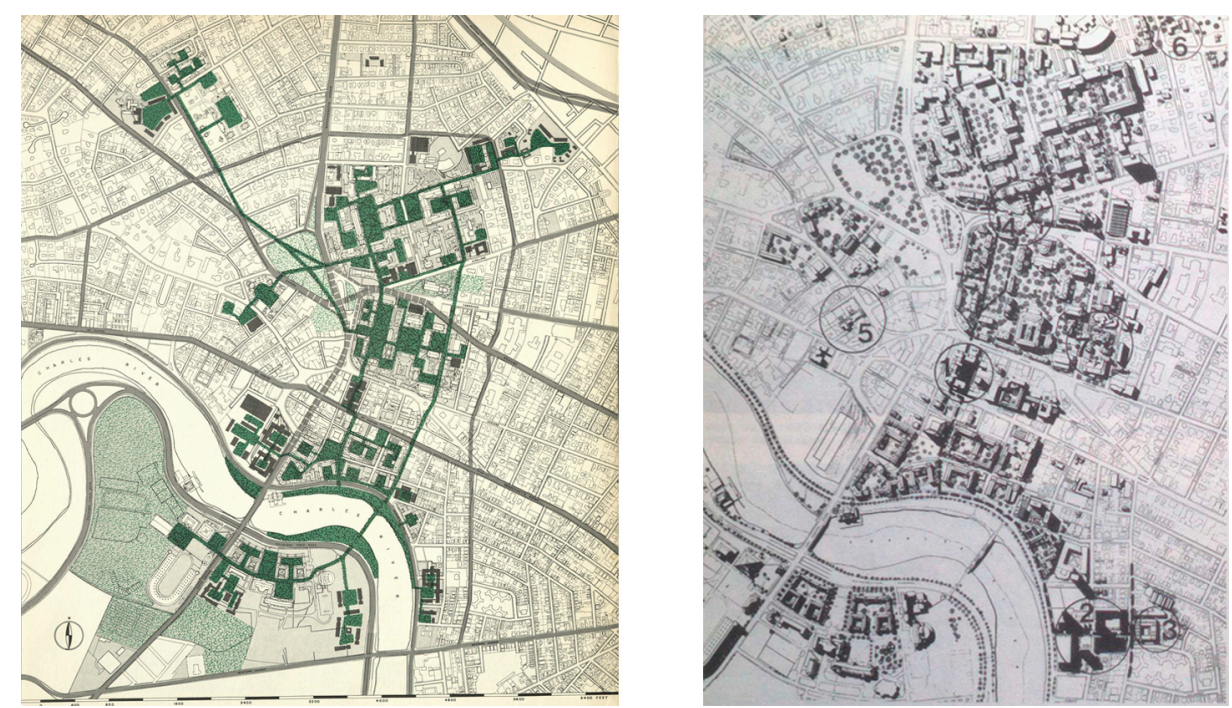

Fig. 3. "Iconic" plans for dissemination of Harvard Planning. Left: book written by Sert and his collaborator Bestlund [11]; university community floor plan, highlighting a system of open spaces connected by pedestrian paths and represented with green frames linked by continuous thick lines of pale gray color. Right: book written by Freixa, [12] former collaborator of Sert; floor plan without the previous green hatches. It is a proud representation of "achievements." Sharpening the look, we see that the buildings of Le Corbusier(7), the married residence(2), the science center(4) are drawn. In addition, this is enhanced by a numbered list of buildings and, coded by shadow cast that reveal their great heights.

They are, in a way, graphic records of a "before and after." And, it is confirmed that the intention of the "iconic" drawings evolves over time. In fact, the second drawing, although referring to Harvard planning is not part of the original document, it is a "redrawing" focused on recording the human scale of the city defended by Sert. 
Much later, Rovira, without a professional relationship with Sert, chooses the latter in black and white as the only representation of this planning for his books [4] [13]. He insists on valuing this work with the "achievements" of the proposed urbanity.

And surely, this "achievement" of vertical density injection is the most significant urbanistically and graphically! Therefore, pedagogically, narrated basically in graphic form.

However, in reality, the urban proposal is part of a planning document of future facilities for the university, which is guided by the conviction of effectively integrating university and city.

\section{$3 \quad$ A graphic narrative}

A document is bound, with 60 folios printed on both sides, composed globally and rationally [13], with text on the left pages and plans on the right, so that open, effortlessly relates the descriptions of the text with the information of the plans. In a way, it resembled the presentation formula of the architecture illustrated magazines that were successful in those times: large images, accompanied by supporting texts and headlines.

Sequentially, those ideas that according to Sert configure the functional city were presented. They are illustrated with diversity of registers and graphic intensities, until reaching a result of modern buildings that are understood to be absolutely integrated in an urban fabric of a city that respects and dialogues with the traditional physiognomy and, with the "modern" myth of living in nature. A certain "vintage" alchemy strange in the initial purist utopias of functionalism.

In a more focused way of seeing over the whole than on each component separately, intentions are revealed that go beyond simple technical, or aesthetic criteria, or sensitivity of each of the drawings or the overall of them. A clear storytelling intention is interpreted, to tell what is proposed and why it is proposed. The sequence of graphic records presented in a way that is full of connections confirms this statement.

Only by looking at the covers of the sections (Fig.4) in which the document is divided, without imagining much, is the continuous growth of the city perceived as the origin, and finally, new buildings that respond to that "assumed" need for growth. It is not a new narrative, but in this case, the fact is that the answer is implemented soon. And this it is significant, especially in the world of urban planning.

Through concatenations of images, and limited graphic resources, a future attractiveness of modern homes is dreamed. At the end, some technical representations, in plan accompanied by perspectives, have just set in the reader the hypnotizing materiality of the dream (Fig.5).

The question arises: does a university planning document have the ultimate goal of building new homes with modern comforts? Perhaps yes, but it is very likely that this was not the main assignment. Surely, it has more than one explanation. The most possible is that it is a way to approximate the proposal to a bewitching future for the general public, whether citizens or university students. Anyone dreams and imagines enjoying a home equipped with modern features, dressed in blue "sky". 


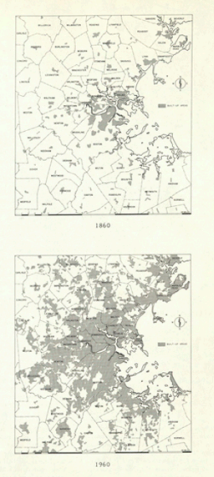

BOSTON METROPOLTAN ARTA
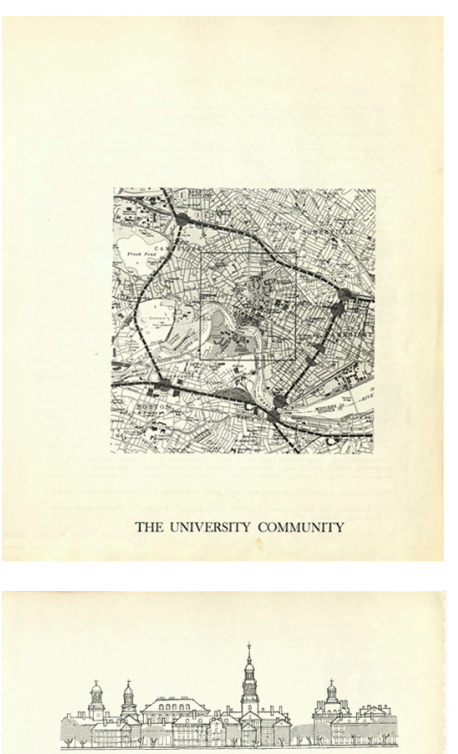

THE FUTURE GROWTH OF THE UNIVERSITY

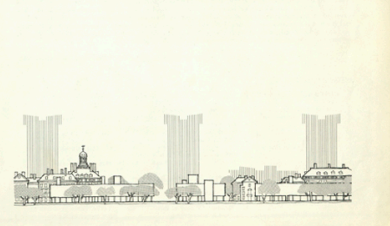

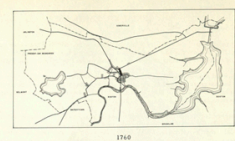
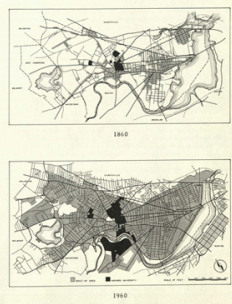

THE CTTY OF CAMBRIDG

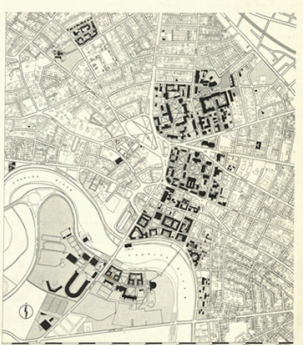

THE UNIVERSTTY

PROBLEMS FOR THE FUTURE

Fig 4. Sequence of "covers" singled out by the white predominance. They synthetically narrate an origin and an ultimate goal. Up-left: initial cover p.1-1. Down-right: final cover. p.7-1. Source: An Inventory for planning, HUPO (1960) [5]. 
In fact, the story shows that "the ultimate goal of the city is housing" [15]. Specifically, the last drawing of the document, graphically describes a new residence for students. Singular ending for an inventory of a university. However, the few implementations of previous functional planning warned about the need to look for new representation strategies. The innovative aerial views did not seem effective enough.

The surprise arises! Although the need to implant density in height is obvious and, this could be controversial, unlike previous plans, he avoids drawing explicitly in elevation or perspective, so any new high-rise building. Sert has known the problems of the city for years and knows how to respond to them. In addition, he also has known for years how to spread ideas, or even how to influence public opinion through the media [16]. And, on that was Sert!
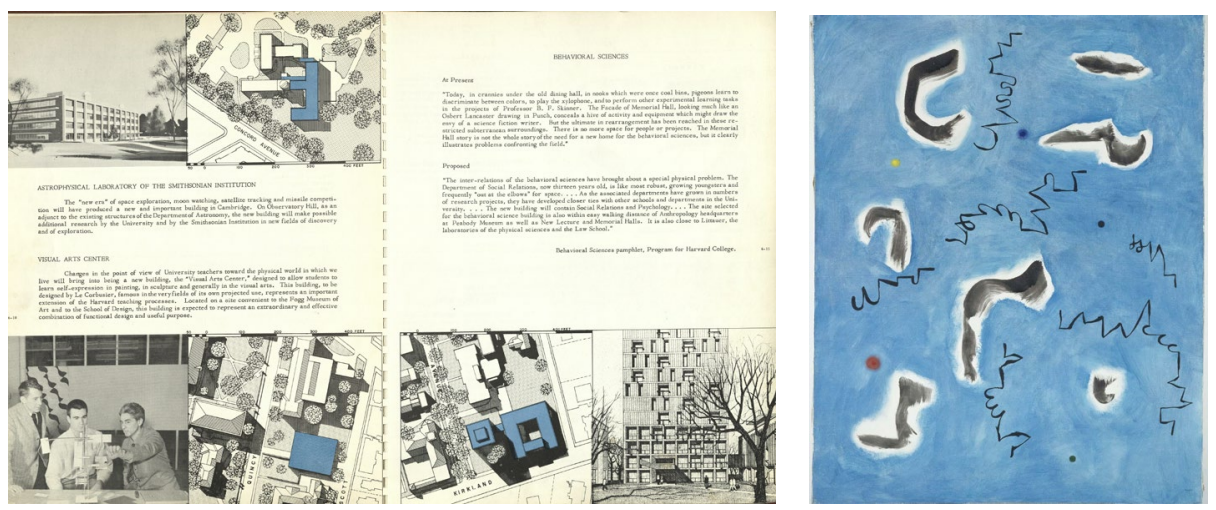

Fig. 5. Result of modern buildings described graphically with an artistic expressiveness. Left: drawings of the inventory of new buildings. Source: An Inventory for planning, HUPO (1960) [5]p.6-10, p.6-11. Right: Joan Miró, Oiseaux dans l'espace (1946). Source: www.museoreinasofia.es

He decides to transmit the ideas of the university integrated growth together with the city, through an attractive graphic format -comfortable and easy- for a large audience, such as an illustrated magazine, where the visual component is basic! He discards more technical formats aimed only at expert readers. He relies on his experience in publications of great diffusion so that the graphic presentation of his ideas embellishes both the university community and the group of citizens, whether experts or laymen. He knew that visual language was memorized more than linguistic; and more, those images with a certain abstraction that still maintain clear links with their referent. In other words, images with a certain ease of reading accompanied by a slight effort to understand the message.

\section{$4 \quad$ Before and after}

In any graphic register, ordering the elements is considered a key in the intention of "understanding" the creative process of the designer, and "making it understood" to 
the public. The order and structure make the story readable. In this sense, Sert provides it to the general public, carefully orders his planning arguments and intentionally manages the types of images and graphic techniques.

He understands that the final goal of the work is the identification of projects series of new buildings for the university that solve the growth needs of the city, but at the same time, he avoids raising misgivings in the rest of the citizens. Thus, in these two senses, the document is structured in two parts: the first about urban reasoning that ensures the harmonious growth of the two communities and, a second part, with a graphic inventory of future buildings (Fig.5).

First, he outlines complicities between city and university, emerging common topics. Thus, an old engraving (Fig.6up) appeals to the pride given to both communities by the historical singularity of the university, the oldest of the British colonies in America.

Following, in a first part, he develops the argument sequentially on different scales: metropolitan area, city, university community and, finally, the university. It makes readable that the metropolitan event conditions the evolution of the university.

The common approach focuses on the graphic story of "before and after". Through this technique, progressively and sometimes repetitively, he highlights the improvements of his proposal on the problems underlined as pressing from a "functional" perspective (Fig.7up). It begins with urban growth, and ends with residential distributions, in between, evaluates public transport, land uses, traffic, public facilities, urban renewal projects, parking, and the network of open spaces and pedestrian paths. The covers of each section graphically synthesize the argument (Fig. 4).

The romantic graphic sequence that connects the story and the open spaces is especially relevant as introduction to the new building list. (Fig.5)

In the second part, a brief introduction of plans with general ideas gives way to the concretion of future buildings. Drawings of diagrams, tables and statistics precede plans, perspective views or schemes of each building. It is an end of sweet promises, "desirable" by all (Fig.5) and, more, seeing that it improves the functioning of the city.

The document prolongs the end with an epilogue of future works and some back covers. It is now the turn of realistic aerial photographs (Fig.7down), large and, in black and white. They insist on visualizing university buildings corseted by a continuous residential urban fabric as the proposal origin.

But, in addition, creative strategies based on the expressive emphasis on the narrative as a whole are observed. There is a clear connection between intentions and images that discard a pure exercise of banality. A completely graphic language of lines, colors, patterns, etc., individually or related to the rest of the illustrations, weaves the consistency and final coherence of the whole document.

It is not just the willingness of expression but it is the creation and construction of a narrative that pretends to persuade, and in that sense, arguments are expressed in a way that is sufficiently impressive. 

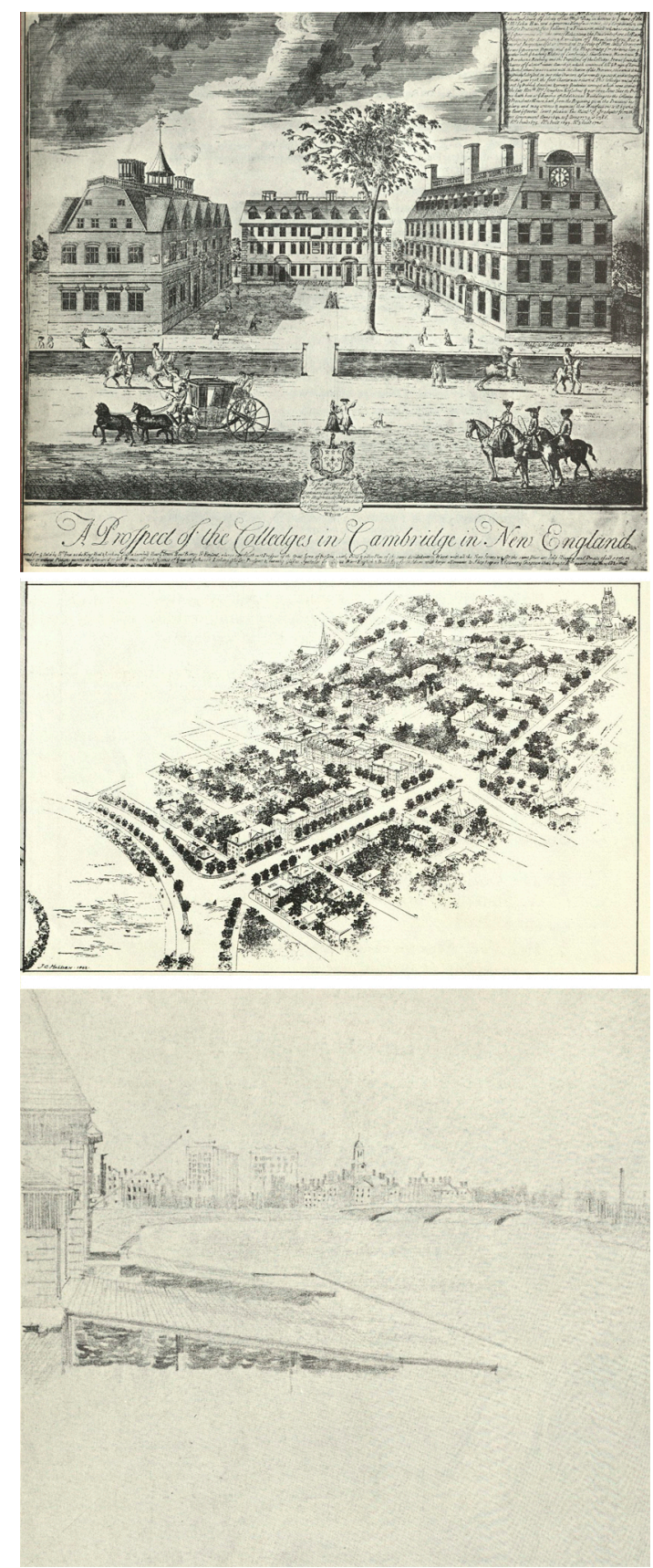

Fig.6. Fig. 6. The "romantic connection" in the story. Up: engraving: view of Harvard in 1743 pag.VI. Center: Study to dignify the approach to Harvard, aerial view (1902) p.4-4b. Down: Walk along the Charles River in Cambridge (1960) p.4-16. Source: An Inventory for planning, HUPO (1960) [5]. 
It acts on parts of the graphic element, on its totality, or on some of its qualities. Narrative compositions are generated by repetitions of elements, or permutations, or substitutions. Thus, for example, the same gray base of the urban fabric is used in the drawings of each of the areas, maintaining same scales, orientations and surface area, illuminating only selected facts. Likewise, the usual practice in functionalist urbanism of repeating colors as coding to represent similar facts is confirmed.
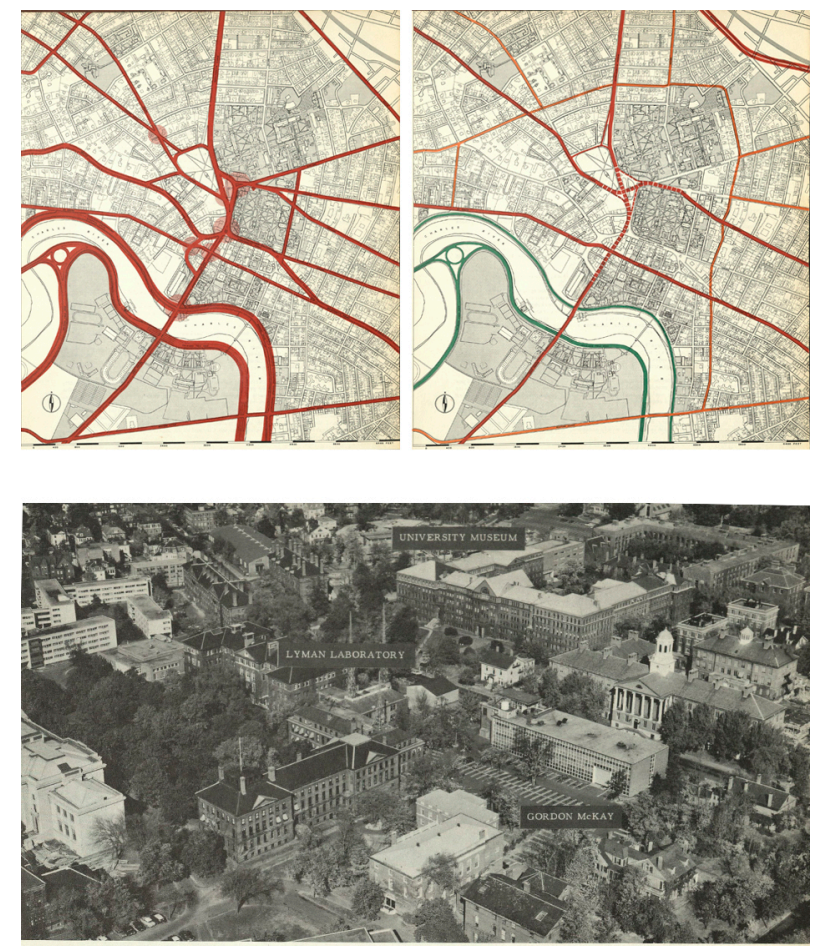

STUDY OF RENOVATIONS AND ADDITIONS TO EXISTING BULLDINGS

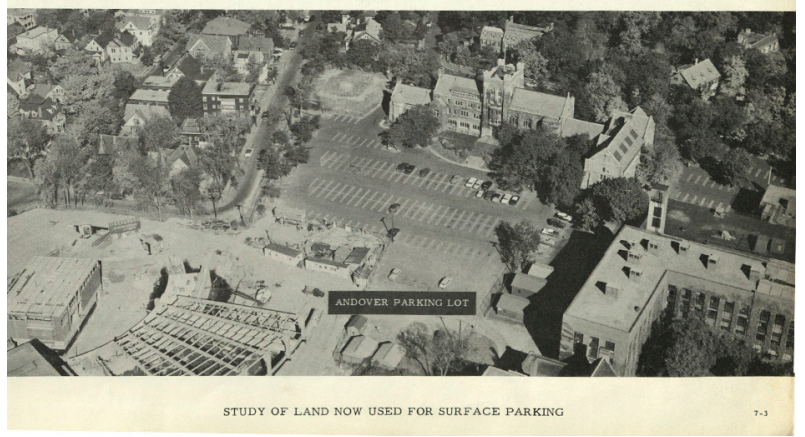

Fig.7. "Before and after". Up-left: Existing traffic flow p.3-7. Up-right: Proposal of road classification p.3-9. Down: Photographies of places for future planning work p.7-3. Source: An Inventory for planning, HUPO (1960) [5]. 
It does not seem coincidental that the plans referring to cars are emphasized with red lines on the gray of the urban plot. It is immediately related to the vitality of blood circulation. However, it is also possible to relate them to the bloody traces of blades that dissect the pale gray of the residential skin (Fig.8up-left), an accentuated perception when seeing the red dots indicating the traffic congestions. Its forms record blood drops. (Fig.8up-right)

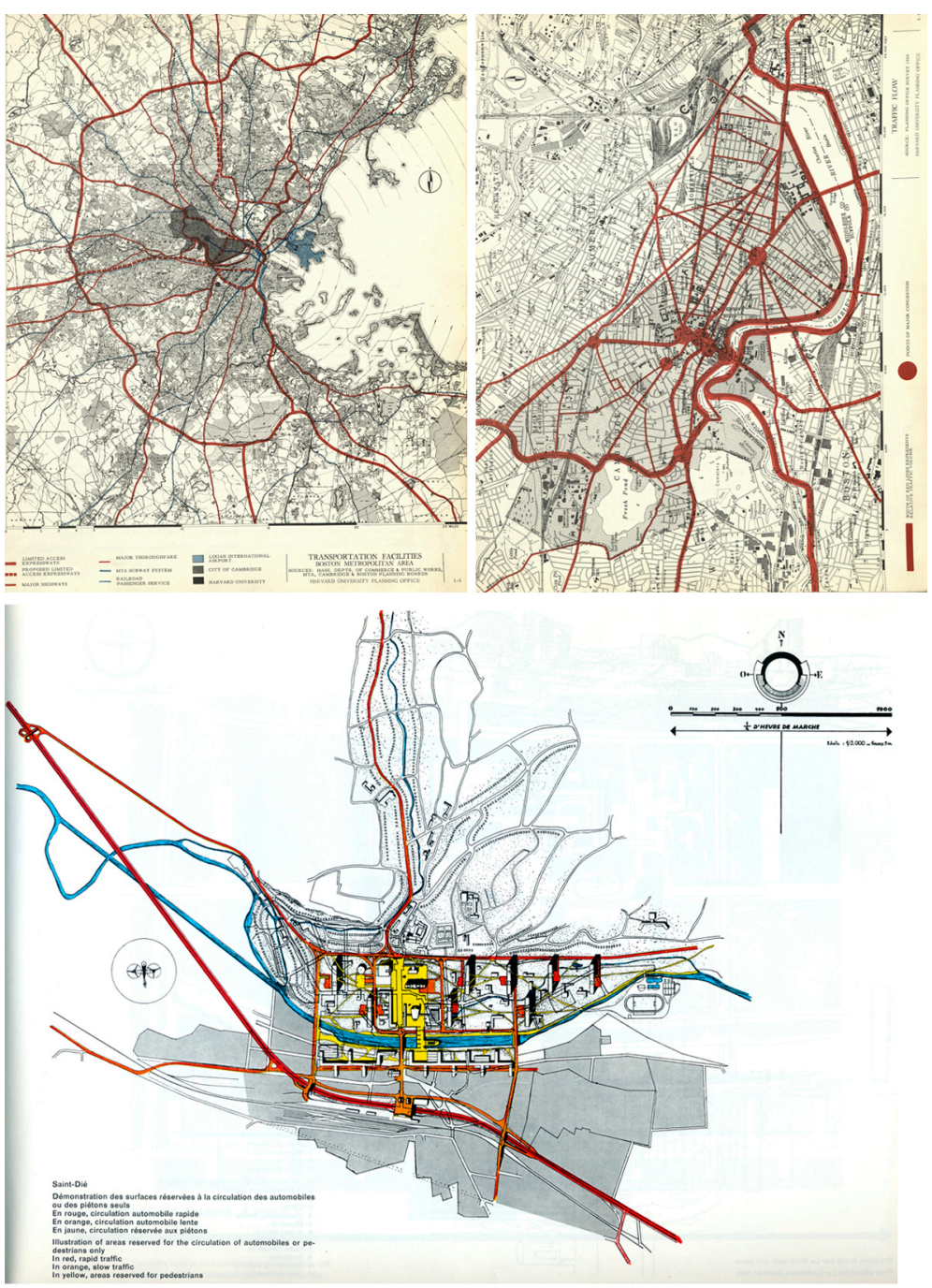

Fig.8. Expressive emphasis by the rhythmic transmission of the same idea: color, repetition. Up-left: roads in the metropolitan area. Source: An Inventory for planning, HUPO (1960) [5]p.1-5. Up-right: road and congestion in the city of Cambridge. Source: An Inventory for planning, HUPO (1960) [5]p.2-7. Down: Planning of Saint Dié de Le Corbusier (1945). Source: Le Corbusier, Complete Works n ${ }^{\circ} 4$ p. 136 
Perhaps the most significantly expressive is the cover of the university growth. Halfway through the document, synthetically, the "before and after" of that space shared by both communities are drawn. Their comparison makes perceive some physiognomies that do not differ significantly. The new tall bodies are drawn abstractly with a texture similar to that of trees (Fig.9up).

Although this blur of skyscrapers seems like a graphic attempt to appease its visual impact, it can also be explained as a manifesto for reducing apparent volumes, as an articulation of the city's large scale in relation to the existing landscape. In short, a friendly fit of the new buildings in the city is perceived. The graphic idea evokes that drawing of the master showing the attractive profile of minarets in Istanbul as a pattern alternating high and low buildings (Fig.9down).

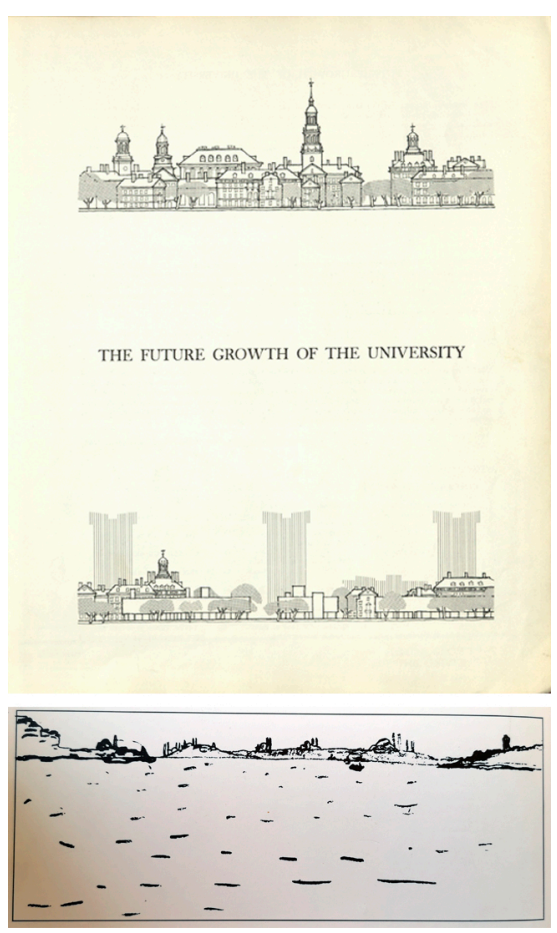

Fig.9. Up: Cover, The future growth of the city. Source: An Inventory for planning, HUPO (1960) [5] p.6-1. Down: view of Istanbul from the Marmara Sea, at the entrance of the Bosphorus, by Le Corbusier (July 1911), source: Voyage d'Orient Carnets AFLC 6128

Being convinced that "if the information presented could find its public, the ordinary citizen would understand the validity and feasibility of rationalist proposals" [17], he materializes a printed document accessible to the general public. The coherent ordering between graphic and conceptual messages allows the reader to memorize a synthetic mental map as a result of an intentional sum of concatenated synthetic messages. 
This is a proposal for the implementation of public facilities argued from a planning "story", and therefore capable of being told to the general public. "The architect has approached them, being able to tell, explain, give a reason for what he does" and, therefore, "becomes more easily understood by who has to assume it" [18]. The construction of the planned buildings, which keep its functionality today, demonstrates the value of this urban theory, but, above all, the value of persuasion of the document.

\section{Conclusión}

Thus, a careful look at the original inventory for planning at Harvard University unveil intentional graphic strategies. It is a material prepared to persuade, and all, through visual resources that rely on communicating a permeability, sensuality and respect among all the communities involved: the metropolitan area, the city and the university. The value of the narrative form, and that of its graphic quality, are key to achieving the predetermined objective of persuasion.
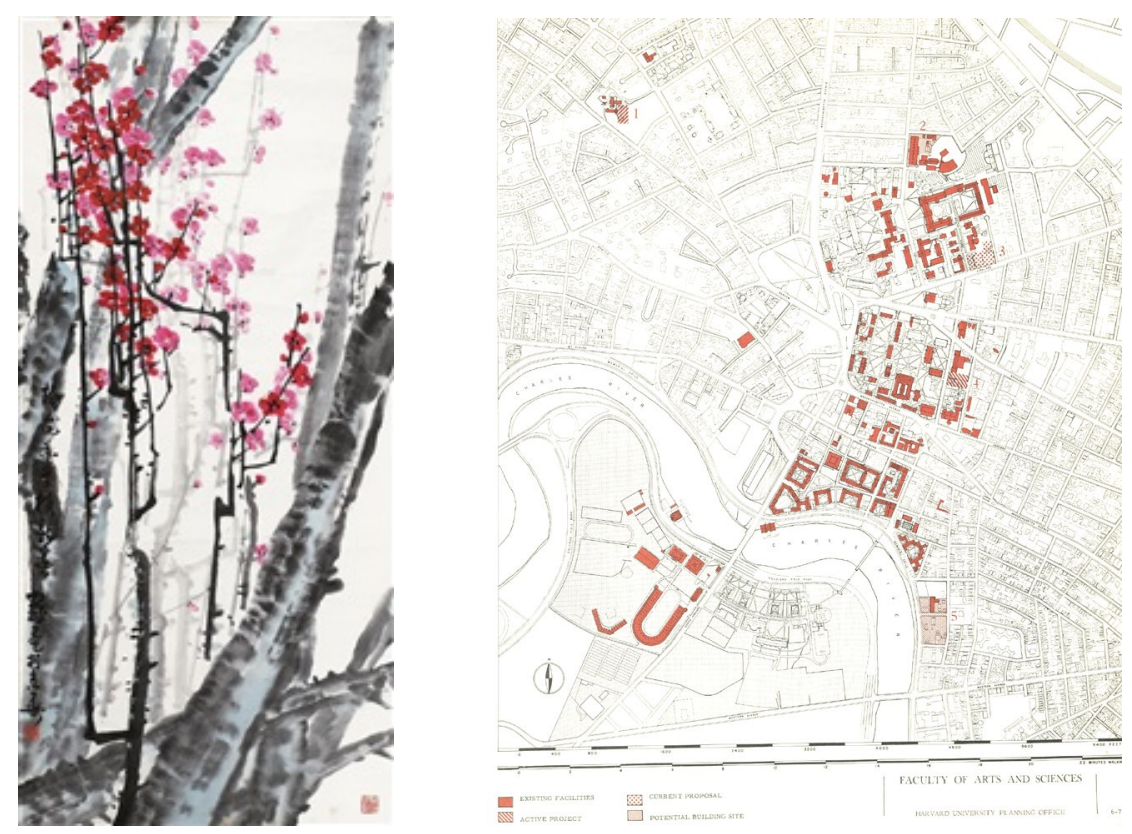

Fig. 10. Artistic expression and architectural representation. Left: Cui Ruzho 红梅 - 镜 心 - 设

色 纸 本,. Right: Harvard University Facilities Plan; Source: An Inventory for planning, HUPO (1960) [5].

At a time when the constant technological advances guide towards representation systems with greater and faster graphic resources, it is opportune, as in a new Renaissance, to reimburse with a new and deep critical sense those graphic patrimonies of the history of Architecture, which as in the case of the legacy of Sert's graphic work 
in Harvard Planning, it contributes to show us, in addition to his urban thinking, a timeless ability to "persuade", concretized through a "shocking" graphic representation and an ordered sequence of images, and where the artistic contribution is essential (Fig. 10) and useful, to make "seductively" perceive those new ideals that will shape the utopian construction of the "modern" city.

Time has shown that, despite the daring proposal, the university and the city have been configured in their sense, and this makes their "graphic narration" as a persuasive reference of success.

It is a way of doing usually forgotten, or diffused in the teaching of Architectural Representation which is mostly focused on working on one or several isolated images, disconnected from a larger set of drawings and abandoning all narrative ideas. This form of restriction limits the achievable power with a graphic story, while preventing modeling a more intense mental image of memories and meanings of the transmitted arguments.

It consists on a mode of drawing, "of revealing and hiding" that not only "is understood" in the individual value of a drawing by itself, but in the value of a set of drawings, all of which are understood as part of a unit. In somehow, it reminds to the way of organizing documentation in an exhibition, or "how to tell a story" [19], or even more distant, to represent perceptions embedded in memories and meanings of a city [20].

The study of this document helps to show graphic narrative resources that improve the ability to communicate ideas more persuasively. Therefore, seeing the importance that this currently has, it is evident the interest of this type of resources for architects, and even more, for those who have to teach them. 


\section{Acknowledgements}

All images from An Inventory for planning, HUPO (1960) are Courtesy of Frances Loeb Library. Harvard University Graduate School of Design,

\section{References}

1. Vesely, D.: Architecture in the age of divided representation: The question of creativity in the shadow of production. Cambridge, Ma.: MIT Press. (2004)

2. Mumford, E., \& Mostafavi, M.: The writings of Josep Lluis Sert. New Haven and London: Yale University Press. Pp.13 (2015)

3. Roca, E.: Campus y Ciudad, la experiencia del Barcelona Knowledge Campus. Revista Iberoamericana de Urbanismo $n^{\circ} 5$, pp.97-105 (2011)

4. Rovira, J.M.: José Luis Sert : 1901-1983 (English ed.). Milano: Electa Architecture: distributed by Phaidon Press. (2003)

5. Harvard University. Planning Office. (1960). Harvard University, 1960; an inventory for planning. Cambridge, Mass.: Harvard University Planning Office.

6. Millan-Gomez, A.: Polémicas berlinesas. Representaciones en la obra de Mies van der Rohe, años veinte. EGA Revista de Expresión Gráfica Arquitectónica, nº13. Pp. (2008)

7. Amado, A.; Fraga, F.: El dibujante digital. Dibujo a mano alzada sobre tabletas digitales. EGA: Revista De Expresión Gráfica Arquitectónica, n²5. (2015)

8. Mumford, E., Sarkis, H., Turan, N., Hyde, T., Sekler, E., \& McAtte, C.: Josep Lluís Sert: The architect of urban design, 1953-1969. New Haven: Cambridge: Yale University Press; Harvard University Graduate School of Design. (2008)

9. Rubert, M.: Ciudades en América Latina. En Sert Arquitecto en Nueva York. Barcelona: Museu d'Art Contemporani de Barcelona - Actar (1997)

10. Freixa J.M.: Josep Ll. Sert ( $1^{\mathrm{a}}$ ed. Catala/portugues. Ed. Obras y proyectos) Barcelona: Gustavo Gili. (1979)

11. Bastlund, K., Sert, J., \& Giedion, S.: José Luis Sert: Architecture, city planning, urban design. New York : Zurich: F.A. Praeger ; Verlag für Architektur (Artemis) (1967)

12. Freixa, J.: Josep L1. Sert (1.a ed. español/ingles. ed., Obras y proyectos). Barcelona: Gustavo Gili. (1989)

13. Rovira, J.M.: Sert half a century of architecture: 1928-1979, complete work. Barcelona: Fundació Miró. (2005)

14. Granell, E., Redondo, E.: Los dibujos de proyecto de J.L. Sert para la fundación Joan Miro de Barcelona; EGA: Revista de Expresión Gráfica Arquitectónica, n²2 (30), pp 224-237 (2017)

15. Le Corbusier. El regalo de los Técnicos (1952)

16. Mendelson, J.: Sert y la imagen, creating a public for Modern Architecture: Sert's use of image from GATCPAC to the heart of the City. DC Papers, $n^{\circ} 13-14$, pp. 130-139 (2005)

17. Sert, J.L.: Can our cities survive? An ABC of urban problems, their analysis, their solutions. Cambridge, London: Harvard University Press, H. Milford, Oxford University Press. (1994)

18. Moneo, R.: La construcción del relato Nueva sede del BBVA Madrid, España. Arquitectura Viva, $n^{\circ} 186$, pp 26-35. (2016)

19. Garcia Marquez, G.: Como se cuenta un cuento. E.I.C.T.V. Madrid: Ollero \& Ramos. (1995)

20. Lynch, K.: The image of the City. Boston, Mass.: MIT Press (1960) 


\section{Author Biographies}

Jesus Esquinas-Dessy. PhD Architect by the University Polytechnic of Catalunya (2013). Master in Landscape Architecture by the ETSAB of Barcelona (1994). Architect by School of Architecture of Barcelona (ETSAB, 1989). Associated professor II (2019) in the Department of Architectural Representation at the UPC, he coordinates and teaches Graduate and Master degree subjects at the Polytechnic School of Building of Barcelona and ETSAB. Assistant Professor (2008-2013) and Associate Professor I (1992-2018). He has taught at international workshops led by the Fachhochschule Hoschschule Technik Stuttgart in Athens and Bordeaux. He is part of the UPC research groups: GREIP and ADR\&M. His field of research focuses on the graphic expression of the architectural project and urbanism. He is the author of several articles and papers in conferences related to her research lines; with a forthcoming essay on Miralles surprising creative process, that win with Isabel Zaragoza the research Prize of XIV Bienal Española de Arquitectura y Urbanismo (BEAU, 2018). He combines his practicing activity with teaching and researching, and his architectural work -fruits of first prizes in architectural competitions-, has been published in specialized magazines and shown in exhibitions.

https://futur.upc.edu/JesusEsquinasDessy

Isabel Zaragoza. $\mathrm{PhD}$ in Architecture at the Polytechnic University of Catalonia (UPC 2015, with Cum Laude), Architect by the School of Architecture of Barcelona (ETSAB, 2001). Degree in Arts and Crafts (Llotja, Barcelona 1985). Serra Hunter Tenure-eligible Lecturer at UPC (2018) and professor at the Architectural Representation Department, ETSAB (UPC, since 2007) where she currently coordinates and teaches Graduate and Master degree subjects. She is membership of the research group ADR\&M-Architectural, Design: Representation and Modelling (UPC). She is the author of several articles and papers in conferences related to her research lines; with a forthcoming essay on Miralles surprising creative process, that win with Jesús Esquinas-Dessy the research Prize of XIV Bienal Española de Arquitectura y Urbanismo (BEAU, 2018). She gets a postdoctoral grant by the Consortium for Advanced Studies Abroad (CASA, 2018) and has been Visiting Fellow at the Harvard University Graduate School of Design (GSD, 2019).

https://futur.upc.edu/isabelZaragozaDePedro

Paula Esquinas. Architect by School of Architecture of Barcelona (ETSAB, 2017) with honors and Masters in Urbanism candidate. She has been studying in several universities as ETSAB (UPC), École Nationale Supérieur d'Architecture de Paris-Belleville in France (ENSA-PB), the University of Texas at Austin, USA, and KU Leuven, Belgium participating in a workshop. She has participated in the international academic competition 'Shanghai Railway Station Competiton', being part of the UPC team, whose proposal was awarded and published in several media. As scholarship awarded for the UPC department of Urbanism at ETSAB (DUOT) she collaborated in a European academic competition. She has collaborated in architecture studios such as Batlle i Roig and Jean-Paul Viguier, working in landscape architecture, public space and urbanism. Since 2016, she has collaborated as an editor at Scalae magazine of architecture. Currently, she combines practice work with research, developing the Master's Thesis in MbArch pre-Doctoral Program in Urbanism at ETSAB (UPC) and working at the department of urbanism of the Area Metropolitana de Barcelona (AMB). 
